\title{
Quantification and viability analyses of Pseudokirchneriella subcapitata algal cells using image-based cytometry
}

\author{
Manuela D. Machado $\cdot$ Eduardo V. Soares
}

Received: 31 March 2014 /Revised and accepted: 3 July 2014 / Published online: 24 July 2014

(C) Springer Science+Business Media Dordrecht 2014

\begin{abstract}
This work aims to evaluate the feasibility of using image-based cytometry (IBC) in the analysis of algal cell quantification and viability, using Pseudokirchneriella subcapitata as a cell model. Cell concentration was determined by IBC to be in a linear range between $1 \times 10^{5}$ and $8 \times 10^{6}$ cells $\mathrm{mL}^{-1}$. Algal viability was defined on the basis that the intact membrane of viable cells excludes the SYTOX Green (SG) probe. The disruption of membrane integrity represents irreversible damage and consequently results in cell death. Using IBC, we were able to successfully discriminate between live (SG-negative cells) and dead algal cells (heattreated at $65^{\circ} \mathrm{C}$ for $60 \mathrm{~min}$; SG-positive cells). The observed viability of algal populations containing different proportions of killed cells was well correlated $\left(R^{2}=0.994\right)$ with the theoretical viability. The validation of the use of this technology was carried out by exposing algal cells of $P$. subcapitata to a copper stress test for $96 \mathrm{~h}$. IBC allowed us to follow the evolution of cell concentration and the viability of copperexposed algal populations. This technology overcomes several main drawbacks usually associated with microscopy counting, such as labour-intensive experiments, tedious work and lack of the representativeness of the cell counting. In conclusion, IBC allowed a fast and automated determination of the total number of algal cells and allowed us to analyse viability. This technology can provide a useful tool for a wide
\end{abstract}

M. D. Machado $\cdot$ E. V. Soares $(\triangle)$

Bioengineering Laboratory — CIETI, Chemical Engineering

Department, ISEP - School of Engineering of Polytechnic Institute

of Porto, Rua Dr António Bernardino de Almeida, 431,

4200-072 Porto, Portugal

e-mail: evs@isep.ipp.pt

M. D. Machado $\cdot$ E. V. Soares

CEB - Centre of Biological Engineering, University of Minho,

4710-057 Braga, Portugal variety of fields that utilise microalgae, such as the aquatic toxicology and biotechnology fields.

Keywords Automated algae counting · Copper stress · Fluorescent dye $\cdot$ Image-based cytometry $\cdot$ Quantitative measure of algae viability $\cdot$ SYTOX Green

\section{Introduction}

Microalgae are receiving major attention as a source of highvalue products, such as pharmaceutical products and biofuels. Part of this significant interest is associated with the ability of microalgae to grow in very inexpensive conditions. Microalgae only require sunlight, carbon dioxide and water (Desai and Atsumi 2013). Microalgae have also been used in aquatic toxicology studies. They constitute the basic link in aquatic food chains and are being widely employed in toxicology studies as a representative of trophic level 1 (Blaise and Vasseur 2005).

Quantification of viable cells in a sample is a central determination, whether in biotechnology or in environmental monitoring. Viability studies are often used in the assessment of toxic impacts. The "gold standard" method of viability determination in microbial models such as bacteria and yeast is the plate count technique. This method is based on the ability, or lack thereof, of a single cell to divide and form a colony on the surface of an adequate agar medium during a period of incubation (clonogenic assay) (Davey 2011). Despite its worldwide use, the plate count method presents some limitations. The assay requires tedious work and many reagents, and only a limited number of cultures can be evaluated simultaneously (Mirisola et al. 2014). It is also known that microbial cells may exist in a state in which they are not able to form colonies but display a measurable cell activity ("viable but not culturable") (Davey and Kell 1996; Davey 2011). In addition, 
microorganisms with a slow growth rate require a long period of incubation and consequently an analysis period of 1 week or higher. This is the case of the green alga Pseudokirchneriella subcapitata (Korshikov) F.Hindák, where its viability determination by the classical plate count method requires more than 1 week. To the naked eye, discernible colonies are only observed after this long period.

Membrane integrity has been used as an alternative criterion for defining cell viability. Plasma membranes constitute a selective barrier between the intracellular contents of a cell and its surrounding environment. Thus, dye-exclusion assays have been used to determine cell viabilities. Cells with damaged plasma membranes cannot maintain an electrochemical gradient and are thus considered dead cells (Davey and Kell 1996). Nucleic acid dyes, such as ethidium bromide (EB) and propidium iodide (PI), have been used in these types of assays. In the case of algal cells, these dyes are inappropriate due to the overlap of the orange fluorescence, exhibited by EB and PI, with the red algal autofluorescence owing to their photosynthetic pigments (chlorophyll $a$ ). Due to this special circumstance, SYTOX Green (SG) seems to constitute an alternative option. This fluorescent probe is excluded from healthy cells with intact plasma membranes, leaving live cells unstained (SG-negative cells). Cells with compromised (permeable) plasma membranes are penetrated by the SG and exhibit a bright green fluorescence and are considered as dead cells (SGpositive cells) (Haugland 2005; Machado and Soares 2012).

Determining algal viability by labelling the cells with fluorescent probes can be obtained in minutes rather than the days or weeks necessary for classical plate counting techniques. However, the processing of several samples by microscopy is labour-intensive and tedious because it requires the counting of thousands of cells by eye (Davey 2011). These drawbacks can be overcome through the use of flow cytometry, which allows the analysis of thousands of cells per second and reduces the statistical error. Nevertheless, such a method remains relatively costly and requires highly skilled personnel (Shapiro and Perlmutter 2006). In recent years, different methods, such as image-based cytometry (IBC) that performs automatic image analysis, have become available at a comparatively lower cost than flow cytometry. IBC combines the use of bright-field and fluorescence image acquisition and processing. The use of this technology has been described in the literature for the evaluation of animal cell viability (Chan et al. 2011b, 2012b) as well as yeast cell viability (Chan et al. 2011a, 2012a; Berkes et al. 2012).

In the present work, we investigated the usefulness of image-based cytometry in the quantification of algal cells and in the determination of cell viability, using P. subcapitata as a cell model. For this purpose, algal populations containing different proportions of heat-treated (dead) cells were labelled with SG. The viability was determined by automated IBC and manually by fluorescence microscopy.
The results obtained by the two techniques were compared. The use of IBC to monitor cell growth and viability of P. subcapitata populations subject to $\mathrm{Cu}(\mathrm{II})$ stress was also evaluated. $\mathrm{Cu}$ (II) was chosen as the toxicant because this metal is a frequently found aquatic system contaminant as a result of urban and industrial inputs. $\mathrm{Cu}$ (II) concentration in surface waters can vary widely and ranges from $8 \times 10^{-3}$ to $16 \mu \mathrm{mol} \mathrm{L}^{-1}$ (ATSDR 2004).

\section{Materials and methods}

Strain, media and culture conditions

The freshwater green alga Pseudokirchneriella subcapitata (strain 278/4) was used. The original strain was obtained from the Culture Collection of Algae and Protozoa (CCAP), UK. The algae were maintained in the OECD algal test medium (OECD 2011) with $20 \mathrm{~g} \mathrm{~L}^{-1}$ agar (Merck), in the dark, at $4{ }^{\circ} \mathrm{C}$. Medium stock solutions were prepared, sterilised and stored according to OECD guidelines (OECD 2011).

The starter cultures were prepared weekly by inoculating a loop of algal cells (from the agar slant) in $20 \mathrm{~mL}$ of the OECD medium, in $100-\mathrm{mL}$ Erlenmeyer flasks. The cells were incubated for 2 days at $25^{\circ} \mathrm{C}$ on an orbital shaker at $100 \mathrm{rpm}$ under continuous "cool white" fluorescent light (fluorescent lamps with a colour temperature of 4,300 K) and with an intensity of $55 \mu \mathrm{mol}$ photons $\mathrm{m}^{-2} \mathrm{~s}^{-1}$ at the surface of the flask.

The pre-cultures and cultures were prepared by inoculating 40 or $100 \mathrm{~mL}$ of the OECD medium in $100-$ or $250-\mathrm{mL}$ Erlenmeyer flasks, respectively, with an initial cell concentration of $\sim 5 \times 10^{4}$ cells $\mathrm{mL}^{-1}$. The cells were incubated for 2 days under the conditions described above for the starter cultures.

\section{Exposure of algal cells to copper stress}

Algal cells from the pre-culture were inoculated in $100 \mathrm{~mL}$ of the OECD medium, in 250-mL Erlenmeyer flasks, with an initial cell concentration of $\sim 1 \times 10^{5}$ cells $\mathrm{mL}^{-1}$ and in the absence (control) or presence of copper. In the latter case, appropriate volumes of $\mathrm{CuCl}_{2}$ were added from standard solutions of $10 \mathrm{mg} \mathrm{L}^{-1}$ (Merck). Cells were incubated for $96 \mathrm{~h}$ under the conditions described above for the starter cultures.

Cell number determination

Cell number was evaluated using three different methodologies, as follows:

1. Measurement of the absorbance at $750 \mathrm{~nm}$, according to US-EPA (2002), and after an appropriate dilution. A calibration curve (number of cells versus absorbance) 
was first constructed. For low cell concentrations, a cuvette with a light path of $4 \mathrm{~cm}$ was used.

2. Direct cell counting using a microscope and a Neubauer counting chamber.

3. Image-based cytometry (see below).

Cell staining and image-based cytometric analysis

Algal cells were centrifuged, washed and resuspended in the OECD medium. Subsequently, cells were stained with $0.5 \mu \mathrm{mol} \mathrm{L}{ }^{-1} \mathrm{SG}$, for $20 \mathrm{~min}$, at $25{ }^{\circ} \mathrm{C}$, in the dark, as previously described (Machado and Soares 2012). Then, a $25-\mu \mathrm{L}$ aliquot of each sample was placed in disposable counting slides (Invitrogen, Life Technologies) and used according to supplier instructions. Image-based cytometric analysis was performed on the Tali (Invitrogen, Life Technologies, USA) image-based cytometer using the green channel (excitation filter, $466 / 40 \mathrm{~nm}$; emission filter, $525 / 50 \mathrm{~nm}$ ). As a positive control (SG-positive cells), the algae were heated to $65{ }^{\circ} \mathrm{C}$ for $60 \mathrm{~min}$. Then, the cells were stained and analysed as described above.

\section{Manual counting using fluorescence microscopy}

Cells were harvested from the culture medium, washed and resuspended in the OECD medium at $1 \times 10^{6}$ cells $\mathrm{mL}^{-1}$. Then, the cells were stained with SG as described above. The cells were observed using an epifluorescence microscope (Leica Microsystems, Wetzlar GmbH, Germany) equipped with an HBO 100 mercury lamp and the GFP filter set from Leica: excitation filter (band pass filter, BP) BP 470/40, dichromatic mirror 500 and suppression filter BP 525/50. Each sample was counted at least four times (total of $>200$ cells per sample) in randomly selected microscope fields.

\section{Statistical analysis}

The data are expressed as the means \pm standard deviation (SD) of three or four independent experiments. Significant differences between the means were tested using the paired Student's $t$ test.

\section{Results}

Quantification of algal cells

The algal cell concentration can be determined using brightfield imaging cytometry. To exclude debris and clusters of cells, a gate between 2 and $12 \mu \mathrm{m}$ (i.e. lower and upper boundaries), corresponding to algal cell size distribution, was selected (Fig. 1a). Within this gate, $99 \%$ of the total events/particles were counted (data not shown). The total number of events/particles was determined after taking the ungated data into consideration. With this procedure, only individual cells that fall within the set boundaries were considered in the population quantification and were included in subsequent fluorescent analysis.

To verify the linearity of the determination, a concentrated cell suspension $\left(\sim 3 \times 10^{7}\right.$ cells $\left.\mathrm{mL}^{-1}\right)$ was prepared and cell numbers were determined by direct counting using a microscope and a counting chamber. From this concentrated cell suspension, several cell populations were prepared in a range between $5 \times 10^{4}$ and $8 \times 10^{6}$ cells $\mathrm{mL}^{-1}$. As shown in Fig. $1 \mathrm{~b}$, a good correlation $\left(R^{2}=0.9998\right)$ could be observed between the expected and observed cell concentrations. The detection limit (DL) was $1 \times 10^{5}$ cells $\mathrm{mL}^{-1}$. The DL was calculated using a section of the curve close to the origin and by also using both the slope and the standard deviation of $y$ residual $\left(S_{y / x}\right)$ (Miller and Miller 2005). The linear range for counting $P$. subcapitata algal cells, using IBC, was between $1 \times 10^{5}$ and at least $8 \times$ $10^{6}$ cells $\mathrm{mL}^{-1}$.

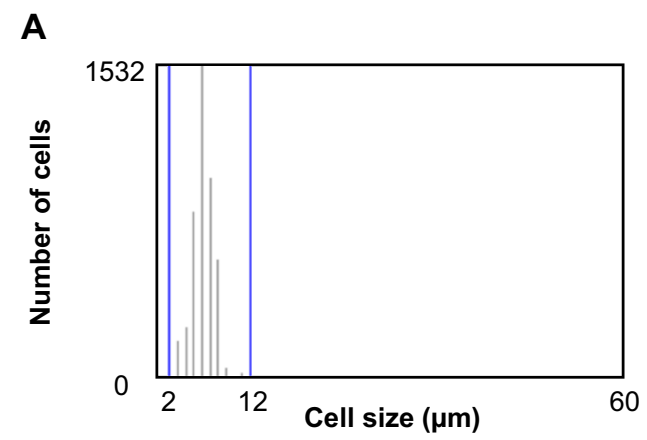

B

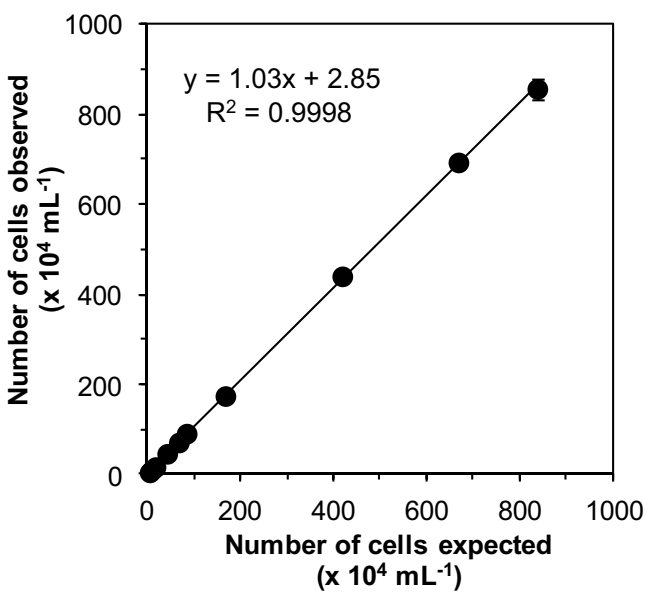

Fig. 1 Use of image-based cytometric analysis for evaluation of cell population of $P$. subcapitata. a Histogram of the size of algae cell distribution. The blue lines represent the lower and upper boundaries selected (a gate between 2 and $12 \mu \mathrm{m}$ ). b Linearity of the determination of algae concentration by image-based cytometry. Each point represents the mean \pm standard deviation (SD) of ten replicates 
Viability analysis in mixed live/dead populations

The feasibility of image-based cytometry in the evaluation of the viability of $P$. subcapitata algal cells was tested. Cells in the exponential phase of growth were used as the viable population (theoretically, $\sim 100 \%$ viability). Dead cells ( $0 \%$ viability) were obtained by heat treatment of cells in the exponential phase. Algal populations with 25, 50 and $75 \%$ of viable cells were obtained by mixing live and dead populations at the appropriate proportions. Algae were labelled with SG and viability was subsequently determined by IBC.

Biological molecules present within cells as well as nonbiological materials can fluoresce upon excitation, resulting in background fluorescence. To exclude background

\section{A Heat-treated cells (\%)}

0

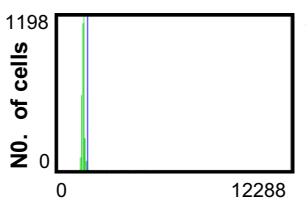

B

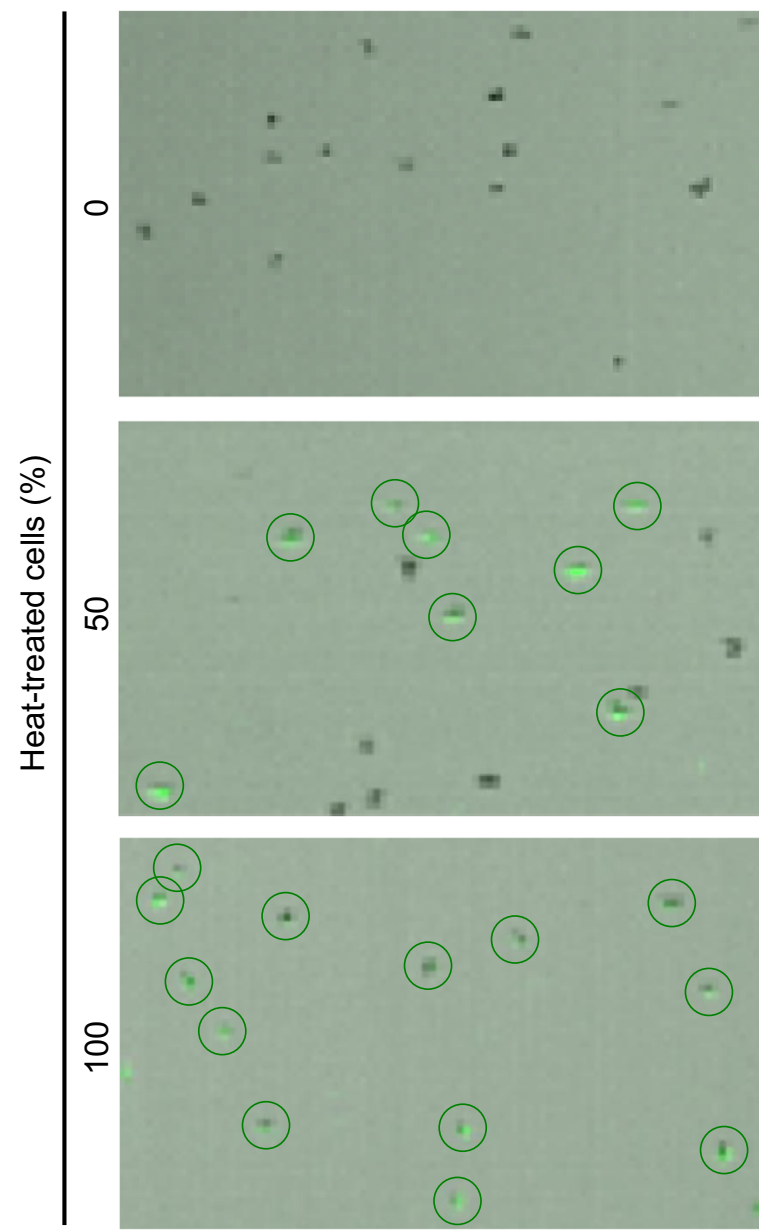

Fig. 2 Assessment of viability by image-based cytometry of mixed live/dead algal cell populations of $P$. subcapitata labelled with SYTOX Green (SG). Different proportions of live and heat-treated $\left(65^{\circ} \mathrm{C}, 60 \mathrm{~min}\right)$ (dead) cells of the alga, at a final concentration of $1 \times 10^{6}$ cells $\mathrm{mL}^{-1}$, were stained with SG. a SG histograms of fluorescence intensity profiles of the different cell populations. The blue line shows the relative fluorescence
50

75

100
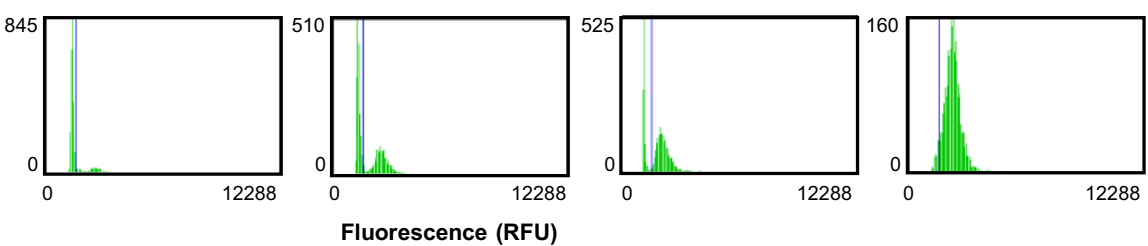

C

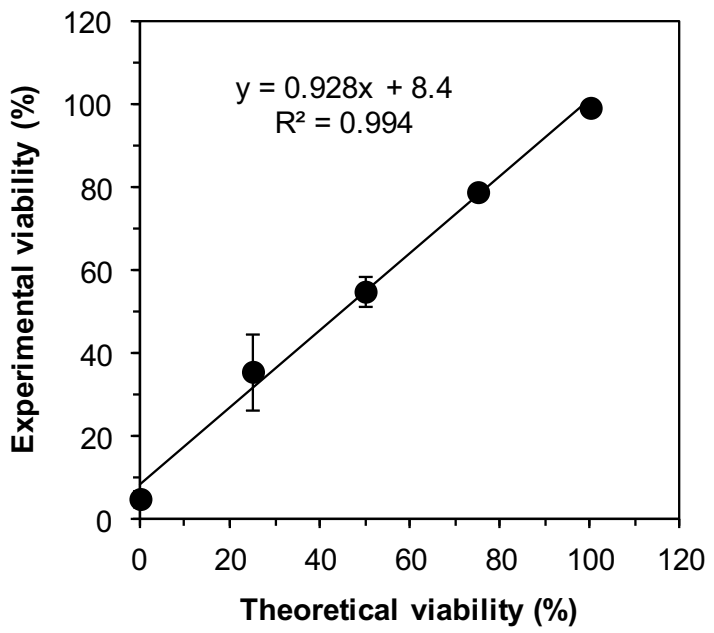

unit (RFU) threshold selected. In each assay, $>5,000$ cells were analysed. b Overlay images of bright-field and green fluorescent channel of different algal populations. SG-positive cells are circled. $\mathbf{c}$ Comparison of theoretical and experimental values of the percentage of viable cells. Data are the mean $\pm \mathrm{SD}$ of three independent experiments 
fluorescence, a minimum (threshold) relative fluorescence unit (RFU) value (Fig. 2a) was defined. For this purpose, algae cells in the exponential phase of growth were used. These cells had an undamaged plasma membrane, were not penetrated by SG and, as a result, remained unstained. The fluorescent threshold corresponds to the "background" fluorescence due to the slide, cells, buffer and dye autofluorescence and appears as the peak closest to the $0 \mathrm{RFU}$ in the histogram "number of cells vs. fluorescence" (Fig. 2a). In each experiment set, the same threshold value was considered. This value was similar among the different experiments.

Only the algae cells with fluorescence levels above the threshold value were counted. The fluorescence threshold was visually confirmed using the image overlay of the bright-field and green fluorescent channels, which allowed us to verify how each individual algae cell was categorised as fluorescent or not fluorescent. The counted algae cells were automatically spotted and circled by the equipment software, which allows for distinguishing between viable and nonviable algae cells (Fig. 2b).

The image-based cytometer used displays a green channel with an excitation filter of $466 / 40 \mathrm{~nm}$ and an emission filter of $525 / 50 \mathrm{~nm}$. This channel is well suited for analysis of cells labelled with SG because this fluorescent probe exhibits a green fluorescence upon binding nucleic acids, with an emission peak of $523 \mathrm{~nm}$ when excited at $450-490 \mathrm{~nm}$. In addition, the band pass emission filter eliminates the P. subcapitata autofluorescence (with an emission peak of $684 \mathrm{~nm}$ when excited at $485 \mathrm{~nm}$ ). In other words, algae autofluorescence does not interfere with green fluorescence analysis. In fact, although live cells displayed autofluorescence, no fluorescence signal could be detected in the green channel (Fig. 2a).

Heat-treated cells exhibited a strong and bright green fluorescence. Algae populations with increased concentrations of heat-treated cells resulted in a peak enhancement (Fig. 2a) due to the presence of green fluorescence (Fig. 2b). Upon comparison, the predicted percentage (theoretical) of viable algae cells was well correlated $\left(R^{2}=0.994\right)$ with the observed percentage (Fig. 2c).

Monitoring of growth and viability of algal cells exposed to copper stress

The validation of IBC used in the analysis of viability was carried out by placing algae cells, incubated in the OECD medium, in the absence (control) or the presence of two copper concentrations, 1.26 and $2.52 \mu \mathrm{mol} \mathrm{L}{ }^{-1}$, which correspond to 80 and $160 \mu \mathrm{g} \mathrm{L}^{-1}$ (ppb), respectively. At defined times (indicated in the graphic), samples were withdrawn for analysis. The concentration of algae cells in the cultures, obtained by IBC, was compared with the result obtained by absorbance at $750 \mathrm{~nm}$. The mean values obtained for the two procedures were not significantly different $(P<0.05)$ (Fig. 3).

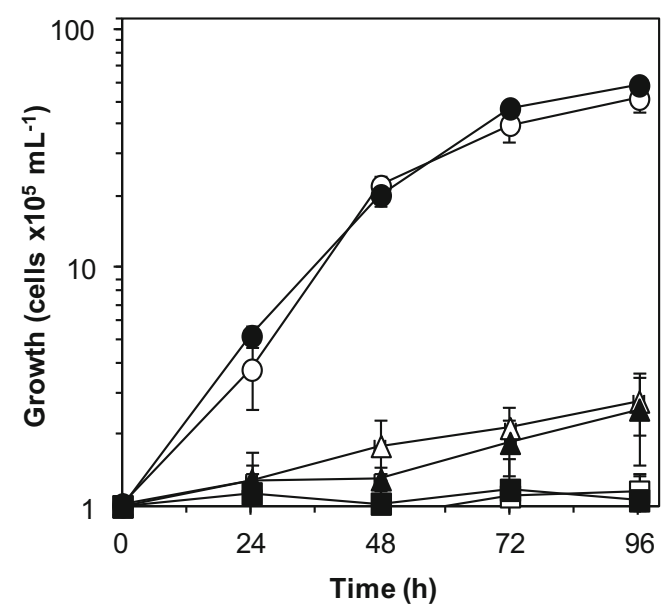

Fig. 3 Evolution of the impact of copper stress on the growth of $P$. subcapitata. Algal cells in exponential phase of growth were inoculated in the OECD medium in the absence (control, circles) or in the presence of different copper concentrations: $1.26 \mu \mathrm{mol} \mathrm{L}{ }^{-1}$ (triangles) and $2.52 \mu \mathrm{mol} \mathrm{L}^{-1}$ (squares). Cell concentration was determined using two different methodologies: image-based cytometry (closed symbols) or the absorbance at $750 \mathrm{~nm}$ (open symbols). Data are the mean $\pm \mathrm{SD}$ of four independent experiments. The means are not significantly different $(P<0.05)$

The incubation of $P$. subcapitata cells with $1.26 \mu \mathrm{mol} \mathrm{L} \mathrm{L}^{-1}$ $\mathrm{Cu}$ (II) for $96 \mathrm{~h}$ inhibited $\sim 95 \%$ of growth. The presence of $2.52 \mu \mathrm{mol} \mathrm{L}^{-1} \mathrm{Cu}(\mathrm{II})$ completely arrested algal growth (Fig. 3).

The evolution of the loss of viability of algae cells in the cultures exposed to $\mathrm{Cu}$ (II) was evaluated by IBC and by fluorescence microscopy. The results obtained by the two techniques were not significantly different $(P<0.05)$ (Fig. 4b). For both copper concentrations, a loss of viability occurred with the time of exposure to the toxicant. The incubation of algae cells with $1.26 \mu \mathrm{mol} \mathrm{L}{ }^{-1} \mathrm{Cu}$ (II) for $96 \mathrm{~h}$ induced a lethality of $\sim 25 \%$ in the cell population. The incubation with $2.56 \mu \mathrm{mol} \mathrm{L}{ }^{-1} \mathrm{Cu}$ (II) for $96 \mathrm{~h}$ resulted in a lethality of $\sim 76 \%$ (Fig. 4). In control cells (not exposed to the toxicant), the percentage of viable cells was $\geq 99 \%$ during the 96-h growth period (Fig. 4). The exposure to $\mathrm{Cu}(\mathrm{II})$ at $16 \mu \mathrm{mol} \mathrm{L} \mathrm{L}^{-1}$ for $4 \mathrm{~h}$ led to a population with more than $99 \%$ of SG-positive cells (data not shown). After exposure to $16 \mu \mathrm{mol} \mathrm{L}{ }^{-1} \mathrm{Cu}(\mathrm{II})$, algae cells were washed, suspended in fresh culture medium at $1 \times 10^{5}$ cells $\mathrm{mL}^{-1}$ and incubated for 7 days. During this time, the population was unable to divide and resume growth, confirming that SG-positive cells can be considered dead (data not shown).

\section{Discussion}

In recent years, several image-based cytometers have become available on the market. These devices acquire both brightfield and fluorescence images, which allows for the 
A

Time (h)
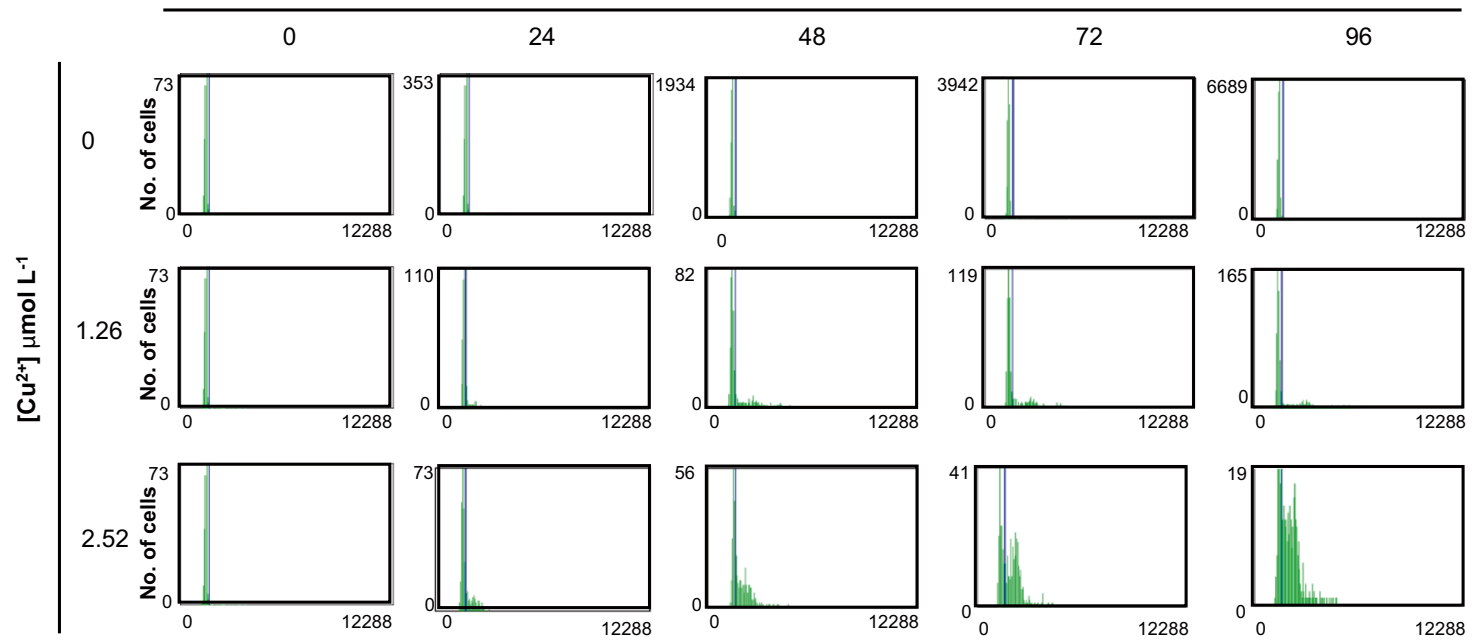

Fluorescence (RFU)

B

$\left[\mathrm{Cu}^{2+}\right] \mu \mathrm{mol} \mathrm{L}-1$
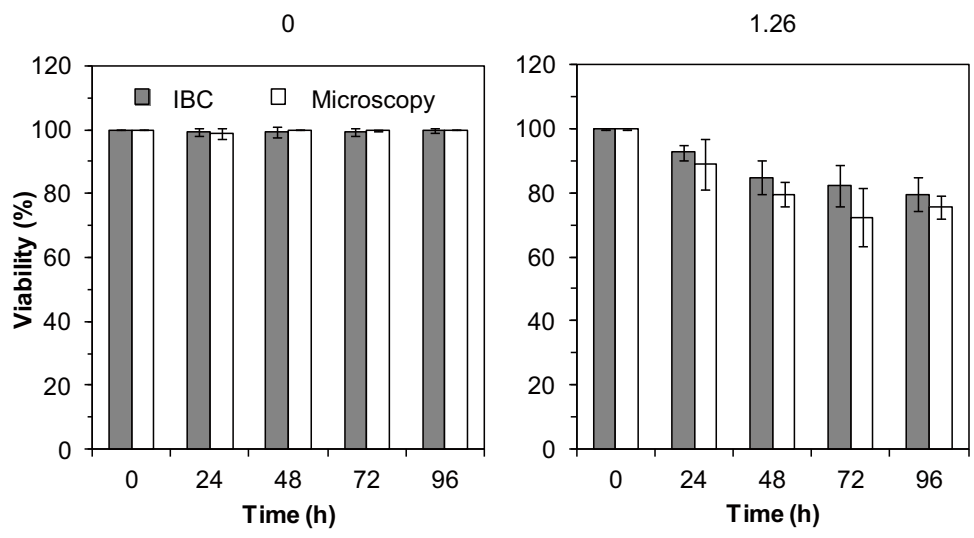

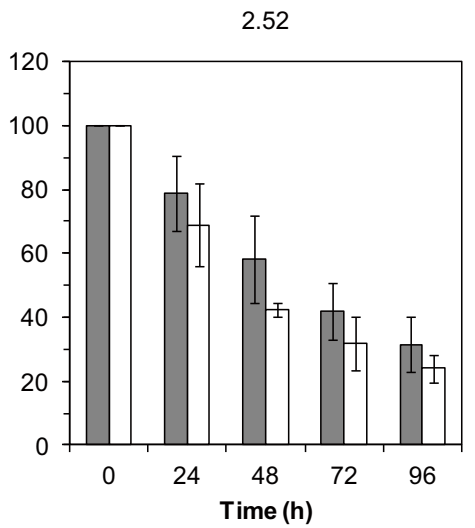

Fig. 4 Evolution of the impact of copper stress on the viability of P. subcapitata. Algal cells in exponential phase of growth were inoculated in the OECD medium containing different copper concentrations. Cells were harvested by centrifugation, washed and labelled with SYTOX Green. a SG histograms of fluorescence intensity profiles of the different cell populations. The blue line shows the relative fluorescence unit (RFU)

simultaneous determination of total cell count and cell viability. Total cell number is counted by the equipment software using the bright-field images, while the viability is determined by analysis of fluorescence images of the same bright-field view (Chan et al. 2012b).

In the present work, the use of this technology with algae cells was evaluated. Debris and clusters of algae cells were excluded from image analysis by selecting a gate between 2 and $12 \mu \mathrm{m}$. The lower and upper boundaries selected correspond to individual algae cell size distribution. These values are in agreement with the data recently reported in the literature, which described an average size (length $\times$ width) of $9.1 \times$ $3.2 \mu \mathrm{m}$ for P. subcapitata (Machado and Soares 2014). It is important to note that a histogram of "cell size vs. number of threshold selected. b Time course of the viability of algal cells not exposed (control) or exposed to copper stress. Viability was evaluated by fluorescence microscopy or by image-based cytometry (IBC). Data are the mean $\pm \mathrm{SD}$ of four independent experiments. The means are not significantly different $(P<0.05)$

cells" is always displayed on the equipment screen. Thus, in each analysis, the lower and the upper boundaries for algal size can be adjusted.

The equipment used allowed for the counting of P. subcapitata cells in a range of between $1 \times 10^{5}$ and at least $8 \times 10^{6}$ cells $\mathrm{mL}^{-1}$. This wide linear range allowed for the monitoring of algal growth (Fig. 3) without the need for cell suspension dilution. These values are in agreement with the supplier, which recommends a sample concentration range of $1 \times 10^{5}$ to $1 \times 10^{7}$ cells $\mathrm{mL}^{-1}$. Chan et al. (2012b), using a different image-base cytometer, reported a similar linear range for animal cells.

The plate count technique constitutes a standard method in the microbiology field for viability assessment. However, the 
slow growth (doubling time of $\sim 12 \mathrm{~h}$ ) of $P$. subcapitata cells (Machado and Soares 2014) makes it difficult to use this method, as it takes 1-2 weeks to visibly observe colonies. In this context, the staining exclusion assay emerges as a good alternative. This technique allows for the visual distinction between viable and non-viable cells. In this work, the criterion of algal viability was based on the exclusion of the fluorescent probe SG. Like the prokaryotic cells, where it is assumed that only cells with plasma membranes that are sufficiently damaged allow the entry of propidium iodide (Davey and Hexley 2011), only P. subcapitata cells with disrupted membranes are penetrated by SG. This means that SG-positive cells have passed the "point of no return" and can be considered nonviable. This possibility was confirmed in $P$. subcapitata, because an algal population that consisted of $>99 \%$ SG-positive cells was not able to grow when incubated in a fresh culture medium for 7 days. SG has been used in the evaluation of the viability of bacteria, yeast cells (Haugland 2005), phytoplankton and green alga, using fluorescence microscopy, flow cytometry or microplate readers (Sato et al. 2004; Ribalet et al. 2007; Timmermans et al. 2007; Segovia and Berges 2009; Rogers et al. 2010; Chang et al. 2011; Nagai et al. 2011; Peperzak and Brussaard 2011; Machado and Soares 2012).

Cell viability, determined by manual counting using fluorescence microscopy, is a labour-intensive method that is conducive to some inconsistency due to user error. In addition, a statistical error is associated with the low number of cells counted. Typically, 100-300 cells are counted. The automated IBC seems to be a useful alternative. This technology reduces the time spent on manual counting, does not require expensive instruments or technical expertise and allows for the analysis of thousands of cells. The labelling of algal cells with SG, followed by IBC analysis, was able to discriminate between live and dead cells. Strong fluorescent signals were obtained from non-viable algal cells. It was also possible to discriminate algal populations containing different proportions of dead cells. The comparison of predicted and measured viability rates showed a high degree of agreement (Fig. 2). Taken together, these results show that analysis by image-based cytometry of SG-labelled algae cells is a useful approach in the evaluation of the viability of $P$. subcapitata. Image-based cytometry also allows for the determination of cell concentrations. Thus, it was possible to carry out the follow-up experiments measuring the impact of a toxicant on cell growth (Fig. 3) and viability (Fig. 4).

In conclusion, image-based cytometry allowed for the accurate measurement of algae cell concentrations and for the evaluation of population viability. It was possible to follow, in a fast and easy mode, the progression of cell death brought about by the addition of a toxicant. Given that image-based cytometry counting is automated, it reduces labour-intensive steps associated with microscopic manual counting, overcomes the subjectivity of personal cell visualisation and allows for the counting of thousands of cells, which improves the accuracy of the results. In addition, this technology combines rapid and automated throughput methods to increase the possibility of visualising cells. Image-based cytometry can constitute a useful tool in aquatic toxicology for the monitoring of algae concentration and for performing viability studies. In a wider scope, IBC can be useful in any determination of algae concentration and viability, which are two important parameters in any cell-based study.

Acknowledgments The authors thank the FCT Strategic Project PEstOE/EQB/LA0023/2013. Manuela D. Machado gratefully acknowledges the post-doctoral grant from FCT (SFRH/BPD/72816/2010).

Conflict of interest The authors declare that this article content has no conflicts of interest.

\section{References}

ATSDR (2004) Toxicological profile for copper. Agency for Toxic Substances and Disease Registry, US Department of Health and Human Services, Atlanta

Berkes CA, Chan LLY, Wilkinson A, Paradis B (2012) Rapid quantification of pathogenic fungi by Cellometer image-based cytometry. $\mathrm{J}$ Microbiol Methods 91:468-476

Blaise C, Vasseur P (2005) Algal microplate toxicity test. In: Blaise C, Férard J-F (eds) Small-scale freshwater toxicity investigations. Springer, Berlin, pp 137-179

Chan LL, Lyettefi EJ, Pirani A, Smith T, Qiu J, Lin B (2011a) Direct concentration and viability measurement of yeast in corn mash using a novel imaging cytometry method. J Ind Microbiol Biotechnol 38: $1109-1115$

Chan LL, Zhong XM, Qiu J, Li PY, Lin B (2011b) Cellometer vision as an alternative to flow cytometry for cell cycle analysis, mitochondrial potential, and immunophenotyping. Cytometry Part A 79A: 507-517

Chan LL, Kury A, Wilkinson A, Berkes C, Pirani A (2012a) Novel image cytometric method for detection of physiological and metabolic changes in Saccharomyces cerevisiae. J Ind Microbiol Biotechnol 39:1615-1623

Chan LL, Wilkinson AR, Paradis BD, Lai N (2012b) Rapid image-based cytometry for comparison of fluorescent viability staining methods. J Fluoresc 22:1301-1311

Chang DW, Hsieh ML, Chen YM, Lin TF, Chang JS (2011) Kinetics of cell lysis for Microcystis aeruginosa and Nitzschia palea in the exposure to b-cyclocitral. J Hazard Mater 185:1214-1220

Davey HM (2011) Life, death, and in-between: meanings and methods in microbiology. Appl Environ Microbiol 77:5571-5576

Davey HM, Hexley P (2011) Red but not dead? Membranes of stressed Saccharomyces cerevisiae are permeable to propidium iodide. Environ Microbiol 13:163-171

Davey HM, Kell DB (1996) Flow cytometry and cell sorting of heterogeneous microbial populations: the importance of single-cell analyses. Microbiol Rev 60:641-696

Desai SH, Atsumi S (2013) Photosynthetic approaches to chemical biotechnology. Curr Opin Biotechnol 24:1031-1036

Haugland RP (2005) The handbook - a guide to fluorescent probes and labeling technologies, 10th edn. Invitrogen Corp, Eugene

Machado MD, Soares EV (2012) Development of a short-term assay based on the evaluation of the plasma membrane integrity of the alga 
Pseudokirchneriella subcapitata. Appl Microbiol Biotechnol 95: 1035-1042

Machado MD, Soares EV (2014) Modification of cell volume and proliferative capacity of Pseudokirchneriella subcapitata cells exposed to metal stress. Aquat Toxicol 147:1-6

Miller JN, Miller JC (2005) Statistics and chemometrics for analytical chemistry. Pearson Education Limited, Harlow

Mirisola MG, Braun RJ, Petranovic D (2014) Approaches to study yeast cell aging and death. FEMS Yeast Res 14:109-118

Nagai T, Ishihara S, Yokoyama A, Iwafune T (2011) Effects of four rice paddy herbicides on algal cell viability and the relationship with population recovery. Environ Toxicol Chem 30:1898-1905

OECD (2011) Alga, growth inhibition test (201). OECD Guideline for Testing of Chemicals. Organization for Economic Co-Operation and Development, Paris

Peperzak L, Brussaard CPD (2011) Flow cytometric applicability of fluorescent vitality probes on phytoplankton. J Phycol 47:692-702

Ribalet F, Berges JA, Ianora A, Casotti R (2007) Growth inhibition of cultured marine phytoplankton by toxic algal-derived polyunsaturated aldehydes. Aquat Toxicol 85:219-227
Rogers NJ, Franklin NM, Apte SC, Batley GE, Angel BM, Lead JR, Baalousha M (2010) Physico-chemical behaviour and algal toxicity of nanoparticulate $\mathrm{CeO}_{2}$ in freshwater. Environ Chem 7:50-60

Sato M, Murata Y, Mizusawa M, Iwahashi H, Oka S (2004) A simple and rapid dual-fluorescence viability assay for microalgae. Microbiol Cult Coll 20:53-59

Segovia M, Berges JA (2009) Inhibition of caspase-like activities prevents the appearance of reactive oxygen species and dark-induced apoptosis in the unicellular chlorophyte Dunaliella tertiolecta. J Phycol 45:1116-1126

Shapiro HM, Perlmutter NG (2006) Personal cytometers: slow flow or no flow? Cytometry Part A 69A:620-630

Timmermans KR, Veldhuis MJW, Brussaard CPD (2007) Cell death in three marine diatom species in response to different irradiance levels, silicate, or iron concentrations. Aquat Microb Ecol 46:253-261

US-EPA (2002) Short-term methods for estimating the chronic toxicity of effluents and receiving waters to freshwater organisms, 4th edn. Environmental Protection Agency, Washington, pp 1-350, EPA821-R-02-013 